\title{
中国雲南省の一農村に㧍ける予防接種活動
}

徐軍 ${ }^{1}$ 松葉 剛 ${ }^{1}$ 丁 峥嵘 ${ }^{2}$ 稲葉 裕 ${ }^{1}$

\section{Immunization activity in a rural village of Yunnan province China}

\section{$\mathrm{XU}$ Jun $^{1}$, Tsuyoshi MATSUBA ${ }^{1}$, DING Zhengrong ${ }^{2}$ and Yutaka INABA ${ }^{1}$}

Objective: This survey was conducted to earn the data for the improvement of the activity of expanded programme on immunization (EPI) in Yunnan province by obtaining the information on knowledge, attitude and practice (KAP) of the mothers for EPI.

Method: The questionnaire survey was conducted for the mothers with infants from 2 months to 6 year old in the villages of Donggua town Zhuxiong prefecture Yunnan province China in 31st October 2002.

Results: There was no statistically significant difference about the relationship between the immunization coverage and KAP of mothers. There found the tendency that the literacy raised the immunization coverage although the statistically significant difference was not revealed. The factor on resident status affected mostly to the coverage as same as the results of the past surveys, namely, the coverage among the floating population was lower than that of the settled. It indicated obviously that the information on EPI from the near community members was most useful among all information sources.

Key words: Yunnan, EPI, BCG scar, floating population, literacy 中国，雲南省， $\mathrm{EPI}, \mathrm{BCG}$ 瘏痕，流動人口，識字率

\section{１緒言}

予防接種は小児期の重症な感染症を予防し, 小 児の死亡を低下させる上で大きな役割を果たして きた。WHO（世界保健機関）は1974年より世界 的規模で拡大予防接種計画 (以下 EPI) をス夕ー トさせ, 今日その対象となる $\mathrm{BCG}, \mathrm{DPT}$, 麻疹, ポリオのワクチン接種率は全世界的に $80 \%$ 以上
になっている，中国においても，1996年には全 国調査によると接種率 $85 \%$ の目標を達成するに 至っている（邵・周, 2001). しかし, 経済発展 による流動人口の増加や一人っ子政策など, 様々 な問題により特定の集団や地域ではいまだに接種 率は不安定である。これら接種率の低いいわゆる ハイリスク集団・地域の接種率を向上させること は，中国国内のみならず日本を含む近隣諸国への

\footnotetext{
${ }^{1}$ 順天堂大学医学部衛生学講座

${ }^{2}$ 中国雲南省疾病予防控制中心免疫規画科

${ }^{\prime}$ Department of epidemiology and environmental health Juntendo university school of medicine

${ }^{2}$ Division of programming immunization Center for disease control and prevention of Yunnan China
} 
夢延を予防するためにも重要である（胡・丸井, 2000). 調査を行なった雲南省は, 山岳地帯が大 部分を占め, また少数民族が多いこと, ミャンマ 一，ラオス，ベトナムと国境を接していることな ど，多くの困難な問題を抱えていることから中国 ではハイリスク地域に含まれる（陸・丁，2001）。

本調査は雲南省楚雄イ族自治州楚雄市の近郊に ある農村をフィールドにし，EPI活動の現状およ び住民の EPI活動に対する知識, 態度, 実践度を 知ることにより，今後のEPI活動に資するデー夕 を得ることを目的に行なわれた。

\section{II 研究方法}

2002 年 10 月 31 日, 雲南省楚雄市東瓜鎮の農村 にて，生後 2 か ～6歳までの小児をもつ保護者 （主に母親）を対象とし，質問紙による面接調査 を行なった．鎮衛生院の職員の案内のもと，村の 中心地において無作為に抽出した家から，2グル ープで時計回りと, 反時計回りに村内を回ること で，無作為性が保たれるようにした。また，倫理 的配慮として, 調查を行なう際に対象者に調查目 的を説明し，同意を得たものにのみ調査を行なっ た。

\section{III 研究結果}

個人特性別に集計結果を見ると，居住形態につ いては, 流動人口 4 名, 定住人口 27 名であった. なお流動人口とは，中国における居住形態の分類 で，定住人口に対しそれ以外のものを指す．都市 への流入人口や船上生活者, 遊牧民なども含まれ る. 本調查の対象者に関しては他地域からの流入 者を指す，民族については，イ族 4 名，漢族 27 名 であった．職業については 30 名が農民であり， 流動人口の 1 名のみが鉭治屋であった。読み書き

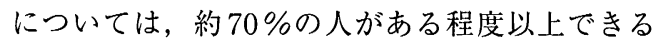
と答えた。供の性は男児 12 名, 女児 17 名, 不 明 2 名であった．兄弟姉妹数は一人っ子が16名, 二人兄弟姉妹が 15 名であった. BCG 痏痕が見ら れたのは $70 \%$ 弱であった（表1).

対象者の知識については, 「予防接種を知って
いるか」との問いに対して，知らないと答えたの は2名であった。 2 名とも流動人口であり, 子供 に瘏痕は見られなかった。「予防接種は子供のた めになると思うか」という質問に対して，予防接 種を「知っている」29名は全員が「思う」と答 えた。予防接種の知識に関する5つの質問につい ては,「予防接種の種類によって受ける回数が決 まっている」という問いを「正しい」と選ばなか った人は 11 人だけであり, 他の 4 問に対して正答 率は 80 〜 90\%以上であった.

対象者の態度については,「予防接種を絶対受 けさせなければならない」と答えた人が 27 人 (90.0\%) であった.

予防接種の実施時期についての質問に対して, 「どちらともいえない」とあいまいな回答をした 人が 12 人，「予防接種会場まで遠い」と答えた人 が1人いた。

次にクロス集計を行い, 以下にあげる作業仮説 を検討した。

(1)保護者の知識不足が接種率を低下させる.

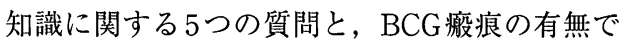
統計学的検定を行ったところ，有意差が見られた のは 1 問のみであった。「予防接種は感染症の予 防になる」と答えた人のほうにBCG 瘏痕有りが 多いといえるが，他の $4 つ の$ 質問については関係 が見られなかった。

(2)保護者の識字率の低さが接種率を低下させ る.

読み書き能力と $\mathrm{BCG}$ 㓔痕の有無で統計学的検 定を行ったところ，有意差は見られなかった。し かし，読み書きができる人では 21 人中痏痕有り が 16 人 $(76.2 \%)$ ，できない人では 7 人中瘏痕有 りが4人 $(57.1 \%)$ であり，有意差は認められな いものの有意な傾向がみられた（ $\mathrm{p}=0.633 ）$.

(3)保護者のその他の個人的特性が接種率を低下 させる.

個人の特性として, 居住形態と民族については, それぞれ BCG 瘕痕の有無とで $\chi^{2}$ 検定を行ったと ころ, 居住形態において有意差が見られた（P= 0.001).このことから保護者が流動人口であるこ 
表 1 予防接種の実践とその要因

\begin{tabular}{|c|c|c|c|c|}
\hline & \multicolumn{3}{|r|}{ 人 (\%) } \\
\hline & & BCG 瘏痕有り & BCG 㓔痕無し & 有意確率 \\
\hline \multirow[t]{2}{*}{ 予防接種はいつ受けても良い } & ‥はい & $1(50.0)$ & $1(50.0)$ & N.S. \\
\hline & ・いいえ & $20(95.0)$ & $6(5.0)$ & \\
\hline \multirow[t]{2}{*}{ 予防接種は 1 回受ければ良い } & ‥はい & $0(0.0)$ & $0(0.0)$ & N.S. \\
\hline & いいいえ & $21(75.0)$ & $7(25.0)$ & \\
\hline \multirow[t]{2}{*}{ 予防接種の種類で受ける回数が決まっている } & ․はい & $13(62.0)$ & $4(38.0)$ & N.S. \\
\hline & ・いいえ & $8(73.0)$ & $3(27.0)$ & \\
\hline \multirow[t]{2}{*}{ 予防接種は感染症の予防になる } & ‥はい & $21(84.0)$ & $4(16.0)$ & $* *$ \\
\hline & ‥いいえ & $0(0.0)$ & $3(100.0)$ & $\mathrm{P}=0.009$ \\
\hline \multirow[t]{2}{*}{ 予防接種で予防できない病気はない } & ‥はい & $1(50.0)$ & $1(50.0)$ & N.S. \\
\hline & ․いいえ & $20(77.0)$ & $6(23.0)$ & \\
\hline \multirow{2}{*}{\multicolumn{2}{|c|}{$\begin{array}{l}\text { 読み書きできる (少しできる（1 人）も含める) } \\
\text { 読み書きできない }\end{array}$}} & $16(76.2)$ & $5(23.8)$ & N.S. \\
\hline & & $4(57.1)$ & $3(42.9)$ & \\
\hline \multicolumn{2}{|l|}{ 流動人口 } & $0(0.0)$ & $3(100.0)$ & $* *$ \\
\hline \multicolumn{2}{|l|}{ 定住人口 } & $21(77.8)$ & $6(22.2)$ & $\mathrm{P}=0.001$ \\
\hline \multicolumn{2}{|l|}{ イ族 } & $3(75.0)$ & $1(25.0)$ & N.S. \\
\hline \multicolumn{2}{|l|}{ 漢族 } & $18(69.2)$ & $8(30.8)$ & \\
\hline \multicolumn{2}{|l|}{ 男児 } & $8(66.7)$ & $4(33.3)$ & N.S. \\
\hline \multicolumn{2}{|l|}{ 女児 } & 13 (81.3) & $4(18.8)$ & \\
\hline \multicolumn{2}{|l|}{ 第 1 子 } & $14(77.8)$ & $4(22.2)$ & N.S. \\
\hline \multicolumn{2}{|l|}{ 第 2 子 } & $5(50.0)$ & $5(50.0)$ & \\
\hline
\end{tabular}

N.S. $=$ not significant

とが，BCG 接種率を低くするといえる．また保 護者の年齢と BCG 瘏痕の有無とで $\mathrm{t}$ 検定を行った ところ，年齢には有意差が見られなかった。

(4)保護者の接種に対する態度が接種率を低下さ せる。

「予防接種を受けさせるのが面倒くさい」「注 射が嫌いだ」と答えた人はいなかった。

(5)母親が忙しくて接種に連れていかれないこと が接種率を低下させる.

「忙しくて時間がない」と答えた人はいなかっ た。

(6)地理的要因が接種率を低下させる.

「会場まで遠い」と答えた人は 0 人で，「時間 がかかる」が 1 人，「交通費がかかる」は 0 人であ った。

(7)子供の個人特性が接種率を低下させる.
個人特性として，性別と第何子かについて，そ れぞれ BCG 㓔痕の有無とで統計学的検定を行っ たところ，両質問とも有意差が見られなかった。 このことから，性別や生まれた順は㓔痕の有無と 関係がないといえる。しかし，第 1 子 18 人中で瘕 痕有りが 14 人 $(77.8 \%)$ ，第 2 子 10 人中㓔痕有り が 5 人 $(50.0 \%)$ であり，統計学的有意差は認め ないものの，第 2 子だと BCG 接種率が低いとい う傾向が認められた．また子供の年齢と $\mathrm{BCG}$ 㓔 痕の有無とで， $\mathrm{t}$ 検定を行ったところ有意差が見 られなかった。

(8)続柄と識字率

続柄と識字率で $\chi^{2}$ 検定を行ったところ，有意 差が見られた $(\mathrm{p}=0.011)$. 男性に比べて女性の 識字率が低く，女性では高齢者に顕著に識字率が 低い. 性別と教育を受けた時代が, 識字率と関係 
表 2 情報提供の有効性に関する検定結果

\begin{tabular}{|c|c|c|c|}
\hline & & & 人 $(\%)$ \\
\hline & BCG 瘏痕有り & BCG 瘢痕無し & 有意確率 \\
\hline 衛生院の情報を職貝から聞いた & $5(50.0)$ & $5(50.0)$ & N.S. \\
\hline 閆いていない & $16(80.0)$ & $4(20.0)$ & \\
\hline 医師から情報を聞いた & $5(100.0)$ & $0(0.0)$ & N.S. \\
\hline 開いていない & $16(64.0)$ & $9(36.0)$ & \\
\hline 村委貝会から閍いた & $9(100.0)$ & $0(0.0)$ & $* *$ \\
\hline 聞いていない & $12(64.0)$ & $9(36.0)$ & $P=0.019$ \\
\hline
\end{tabular}

N.S. $=$ not significant

のあることがわかった.

(9)情報提供の有効性

「予防接種をどこで知ったか」という質問に対 し, 複数回答式でデータを得た。衛生院の職員か ら 10 人，家族から 1 人，友人から 1 人，パンフレ ットから 1 人, TV・ラジオから 2 人, 医師から 6 人, 自分が受けたことがあるからが 3 人, 村医生 加 3 人，村委員会加 10 人，村長加 4 人とい う結果になった。このそれぞれの回答と BCG 㓔 痕の有無とで $\chi^{2}$ 検定を行ったところ, 村委員会 からの情報提供においてのみ有意差が認められた $(\mathrm{P}=0.019)$.

主な情報源となっている衛生院の職員, 医師, 村委員会のうち, 衛生院の職員, 医師からの情報 提供の有無は瘷痕の有無に関係がないが, 村委員 会からの情報提供を受けた人のほうが，BCG 痏 痕有りの割合が高かった（表2）。

\section{IV 考察}

一次集計の結果より，保護者の知識を問う設問 の正答率は $58.1 〜 93.5 \%$ あり，設問によるばら つきが大きかった．とくに何の予防接種か, 何回 受ければよいのかなどに関しては，あいまいな人 が多いようだった。検定結果から知識の有無は, 接種率に大きく影響しないと考える.

態度・実践に関して良好な回答を得たもので は，どの質問も 87.1〜93.5\%と高かった. 予防接 種を受けさせようとする，積極的な態度を持ち実 践している人が多い.
以上のことから，予防接種率を上昇させるため に，「接種を受けに行かなければならない」とい う，強制力を国民に与える行政の方針が伺えた。 これらのことから，中国は保健政策上でトップダ ウンの傾向が強い国であると思われた。

以前の報告（松葉 - 梁, 2000 ; 村上 - 小林, 2001）と同様に,「流動人口」と「定住人口」で は, 流動人口のほうに接種率が低いことが示され た，民族・識字率が交絡因子でないことから，流 動していることそのものが, 接種率の低下に結び ついているものと考えられた. 流動人口の接種率 の低さは, 行政の大きな課題であり, 今回の調査 は標本数が少ないものの, BCG 痏痕有りは定住 人口で $77.8 \%$, 流動人口で $0 \%$, 全体で $67.7 \%$ で あった．流動人口の予防接種対策は，駅・市場な ど流動人口の多い地点で重点的に行い，一般住民 より能動的な参加が望まれる。このことから，そ の必要性の正しい認識が重要である。同時に，広 い地域を移動するケースもあることから，地区， 県, 郷鎮などにとらわれない, 広い地域を把握し た取り組みの重要性も示唆される。

統計学的な有意差はないものの保護者の読み書 き能力が低いと接種率が低い。第 2 子だと接種率 が低い，という傾向が強かった．標本数が大きけ れば仮説は証明されたかも知れない。識字率の低 い女性を中心とした教育環境の整備，第 2 子以降 の小児の正確な人口把握が, 接種率の向上に結び つくものと思われる.

高齢の女性（子供の祖母）の識字率は約 $17 \%$ 
と低かった，彼女たちへの情報伝達は絵の多いポ スターやパンフレット，あるいはTV・ラジオの ような目や耳から情報が入るものの方が有効だと いえる.

情報提供の有無と瘏痕の有無に大きな関係はな いようであった. しかし，村の委員会から聞いた 人のほうが，聞かなかった人に比べて接種率が高 いことが示された．接種率を上昇させていくため には，衛生院の医師よりも住民により身近な，村 などの行政組織からの情報提供のほうが有効では ないかと考えられた。

この調查は, 平成 14 年度順天堂大学医学部 3 年基碟 ゼミナールの衛生学ゼミの参加者 (安藤麻矢, 猪俣武
範，金子淳太郎，野中香苗）の協力を得て行われた。

\section{文献}

邵 瑞太, 周軍 (2001): 中国における予防接種 の成果と展望, 日中医学, 16(4)

胡 飛躍, 丸井英二 (2000): 中国における保健医療 領域の現状と課題，民族衛生，66(5)，216-223

陸林, 丁 峥嵘 (2001)：雲南省の予防接種の現 状と対策，日中医学，16(4)，14-16

松葉 剛, 梁 志松 (2000): 計数抜き取り検查法を 用いたポリオワクチン接種率評価法 中国雲南省少 数民族居住地域での応用, 日中医学, 14(3), 15

村上 仁, 小林 誠（2001）：JICA 中国予防接種事 業強化プロジェクトとその協力活動, 日中医学, 16 (4), $17-20$

(受稿 2003. 3. 14 ；受理 2003.5. 16) 